\title{
ハザード関数を用いた有害事象の好発時期の推定
}

\author{
福島 彰*1,*3, 広岡 禎*1, 柏木 涉*1 \\ 佐野正樹*1, 伊藤国夫*2，大橋靖雄*3
}

\section{Estimation of Occurrence Peaks of Adverse Events Using Hazard Functions}

\author{
Akira FUKUSHIMA*1,*3, Tadashi HIROOKA*1, Wataru KASHIWAGI*1, Masaki SANO*1, \\ Kunio ITOH*2, Yasuo OHASHI*3 \\ *1 Clinical Data Management Dept, Taiho Pharmaceutical Co., Ltd \\ 3 F, Kandabashi Park Bld, 1-19 Kandanishiki-cho, Chiyoda-ku, Tokyo 101-0054, Japan \\ *2 Drug Safety Information Dept, Taiho Pharmaceutical Co., Ltd \\ *3 Department of Biostatistics, School of Health Science and Nursing, University of Tokyo
}

\begin{abstract}
〈Abstract〉
Objective : The incidence rate is used frequently in drug safety assessment. The incidence rate of adverse events is defined as the number of patients experiencing a certain adverse event divided by the number of patients administered a drug in spite of duration of administration (observation). In post-marketing surveillance, the duration of administration (observation) typically differs by patient and most of the analyses fail to take into account the differences in duration of administration (observation). Therefore, we investigated the usefulness of hazard functions in a drug safety assessment using the interim results from Clinical Experience Investigation of the oral anticancer drug, TS-1. Methods : About three thousand patients with gastric cancer were enrolled in this Clinical Experience Investigation. TS-1 was administrated orally twice daily. One course consisted of consecutive administration for 28 days and 14 days rest. Administration was repeated in two courses. Hematological measurements, stomatitis, anorexia, nausea/vomiting, diarrhea, malaise were analyzed. Adverse events were evaluated in accordance with the criteria of the Japan Society for Cancer Therapy, which were established based on criteria established by the WHO. Time to occurrence of an adverse event was calculated from the first day of administration until the adverse event was first observed. Hazard functions were estimated by smoothing methods using kernel functions.
\end{abstract}

Results : The occurrence of adverse events using smoothed hazard functions had one peak around 10 days in the first course and decreased by administration rest. With the resumption of administration, the occurrence increased again. The occurrence in the second course were less than that of the first course.

Conclusion : The occurrence peaks of adverse events were estimated graphically by smoothed hazard functions. We conclude that hazard functions are useful as an analytical tool in drug safety assessment.

Key words : hazard function, smoothing method, kernel function, adverse event

\footnotetext{
${ }^{* 1}$ 大鵬薬品工業株式会社 DM 部 ${ }^{* 2}$ 大鵬薬品工業株式会社安全性情報部 *3 東京大学大学院医学系研 究科

別冊請求先：テ 101-0054 東京都千代田区神田錦町 1-19 神田橋パークビルヂング $3 \mathrm{~F}$ 大鵬薬品工業株式会社 DM 部 福島 彰
} 


\section{緒 論}

医薬品の安全性評価では, 要約指標として発現 割合が頻繁に用いられる。有害事象（副作用）の 発現割合 $(\mathrm{R})$ は, 薬剤の投与期間および観察期間 の長さとは無関係に, 有害事象 (副作用) が発現 した症例数 $(\mathrm{X})$ を薬剤が投与された症例数 $(\mathrm{N})$ で割ったもの $(\mathrm{R}=\mathrm{X} / \mathrm{N})$ として定義される ${ }^{1)}$.治 験では, 治験実施計画書において, 投与期間およ び観察期間が明確に定められているため, 発現割 合は安全性評価の要約指標として適切な指標であ ると考えられる.一方, 市販後の使用実態調査 (以 下，市販後調査という）では，投与期間および観 察期間が長くなるにつれて症例数が減り, 有害事 象（副作用）の発現件数が見かけ上少なくなる.

このため, 発現割合だけで結果の解釈を行うと 有害事象 (副作用) の発現を過小評価してしまう. しかしながら，市販後調查では発現割合を用いて 安全性の評価を行う場合が多く, 症例毎の投与期 間および観察期間の違いを考慮した解析はほとん ど行われていない.

症例毎の投与期間および観察期間の違いを考慮 した解析としては, 有害事象 (副作用) の初発時 期に関して, Kaplan-Meier 法を用いて, 累積発現 率曲線を推定することが考えられる。しかし, 累 積発現率曲線から有害事象 (副作用)の発現パター ン（好発時期）を推定することは容易ではない.

そこで, 有害事象 (副作用) の発現パターン (好 発時期) を推定するために，ハザード関数を適用 することを考えた。TS-1 カプセル使用成績調査 の中間集計 ${ }^{2)}$ を対象として, 安全性評価における ハザード関数の有用性について検討を行った.

\section{方 法}

\section{1. 解析に用いたデータ2)}

TS-1 カプセル使用成績調査の中間集計のデー 夕を用いて解析を実施した。 TS-1 カプセルは, 1999 年 1 月に胃癌の効能で承認された経口の抗 悪性腫瘍薬である。薬剮の適正使用に関する情報 を収集することを目的として, 発売直後から 3,000 例に達するまで, ほぼ全例の使用成績調査
を実施した。

2000 年 3 月までに 4,166 例が登録された。投薬 が開始された 3,883 例のうち 3,321 例の調査票が 回収され, 安全性の評価症例は 3,294 例であった。 何らかの副作用が発現した症例は $74.1 \%(2,441 /$ $3,294)$ であり, 承認時と同様な結果 $83.2 \%$ (233/ 280）を示した。

TS-1 の投与スケジュールは 28 日連日経口投 薬と 14 日間休薬をあわせた 42 日間を基本的に 1 クールとし，使用成績調查では 2 クール終了後に 調查票を回収した。

添付文書には, 投与期間中は 2 週間に 1 回以上, とくに 1 クール目は頻回に臨床検査を実施するこ とが記載されており，1 週間隔あるいは 2 週間隔 で臨床検查の測定および臨床所見の評価を行う症 例が多かった。

\section{2. 解析項目}

TS-1 の臨床検査值データおよび臨床所見デー 夕を用いて, 以下の解析を行った。治験時の TS1 の主な有害事象のうち, 血液学的検査 4 項目 (血 色素量, 白血球数, 好中球数, 血小板数) および 臨床所見 5 項目（口内炎, 食欲不振, 悪心・嘔吐, 下痢，全身倦怠感）を解析項目とした．各項目の 程度については, 日本癌治療学会の「固形癌化学 療法効果増強の判定基準」に従い, G0 (症状なし), G 1 (軽度), G 2 (中等度), G 3 (高度), G 4 (極 めて高度)の 5 段階にグレード分類して評価した。 薬剤との因果関係は問わないが, 記載医師が異常 変動として判断し, グレードが投与前值から 1 段 階以上悪化した場合をイベントとし，イベントの 初発時期に着目して解析を行った。 なお，イベン トの認められなかった症例は, 投与終了日を右側 打ち切りデータとして取り扱った。

\section{3. ハザード関数}

ハザード関数は, 単位時間にイベントが起こる 確率として定義される。単位時間を 1 日とし, $t$ 日 目のリスク集合（ $t$ 日目の直前まで，イベントの 発生していない，薬剤を投与している症例数）を $n(t), t$ 日目にイベントの発生した症例数を $d(t)$ とする.このとき, $t$ 日目のハザード関数は以下の 式 $(h)$ で定義される。 
薬剤疫学 Jpn J Pharmacoepidemiol, 8(1) Sept 2003:39

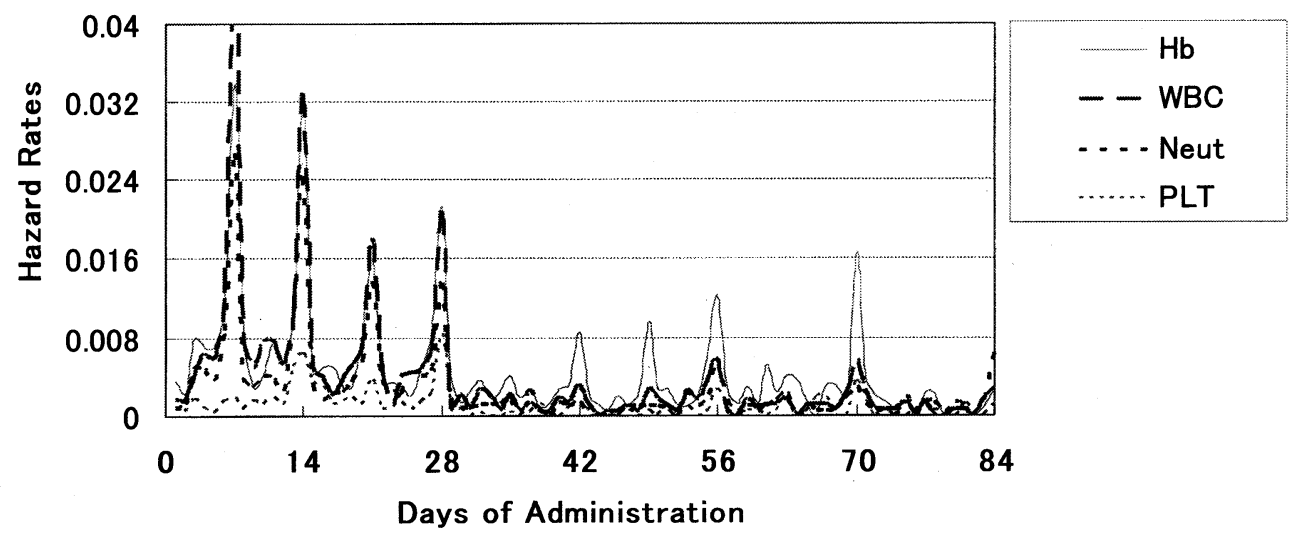

Fig. 1 Occurrences of adverse events using hazard functions

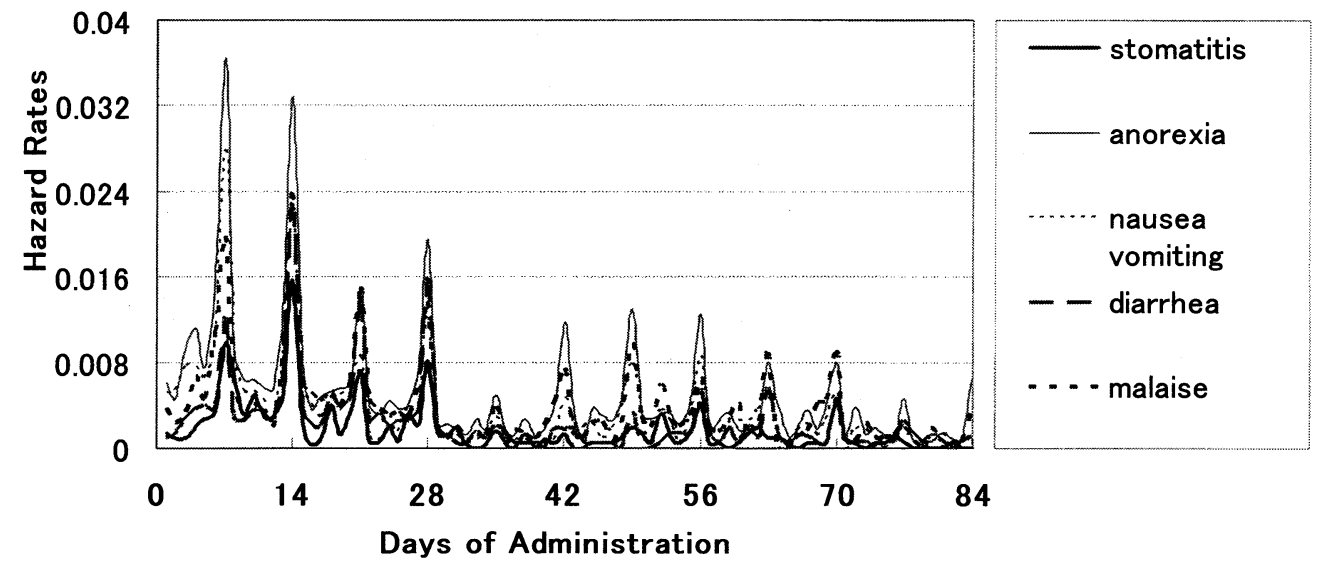

Fig. 2 Occurrences of adverse events using hazard functions

$$
h(t)=\frac{d(t)}{n(t)}
$$

ここで, $t$ 日目にイベントの発生した症例数 $d(t)$ は, $t$ 日目の検査の 1 回前の検査から $t$ 日目での 検査までに発生したイベント数をすべて含んだも のである。

9 個の解析項目に関して, ハザード関数を図示 すると Fig. 1, Fig. 2 になる.

\section{4. 平滑化ハザード関数}

Fig. 1, Fig. 2 の結果より，ハザード関数は投与 日毎（観察日毎）の変動が激しいうえに, 推定量 としても非常に不安定であるため, 平滑化を用い てハザード関数の推定を行った。

本研究では，核関数を用いてハザード関数の平
滑化を行った。 $t$ 日目の核関数による平滑化八 ザード関数は「ハザード関数の重み付き線形和」

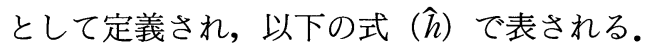

$$
\hat{h}(t)=\frac{1}{b} \sum_{i=1}^{k} K\left(\frac{t-t_{i}}{b}\right) h\left(t_{i}\right)
$$

ここで, $t_{i}$ (日目) はイベントが起きたときの時点 $\left(i=1,2, \ldots, k: t_{k}\right.$ は最終のイベントが起きたとき の時点）である.

核関数による平滑化ハザード関数を算出するた めには, 式 $(\hat{h})$ において $b, K\left({ }^{*}\right)$ を事前に設定 することが必要である。 $b$ は平滑化パラメータと 呼ばれ，重み付き線形和における「線形和を取る デー夕の個数」に対応する。一方， $K\left({ }^{*}\right)$ は核関 数と呼ばれ, 重み付き線形和における「重み」に 
対応する.一般に，平滑化パラメー夕，核関数の 違いによって平滑化ハザード関数の形状が異なる ことも考えられるため，これらの設定根拠につい て以下に記載する。

なお，平滑化ハザード関数の推定は統計パッ ケージ SAS（Ver.6.12）を用いて行った。

\section{1 平滑化パラメータ}

平均 2 乗誤差 $(M S E)$ の最小になる值を平滑化 パラメータとして設定した。平均 2 乗誤差は以下 の式で表される.

$$
M S E=\frac{1}{k} \sum_{i=1}^{k} E\left(\hat{h}\left(t_{i}\right)-\tilde{h}\left(t_{i}\right)\right)^{2}
$$

ここで, $k$ はイベントが起きた時点の数, $\hat{h}$ は平滑 化ハザード関数, $\tilde{h}$ は真のハザード関数 (未知) で ある。

平均 2 乗誤差は分散（バラツキ）の項とバイア スの項に分解できる。平滑化パラメー夕 $(b)$ を大 きくすれば，バラツキは小さくなり滑らかなハ ザード関数が得られるが, バイアスが大きくなる. 逆に，平滑化パラメータ $(b)$ を小さくすれば，バ イアスは小さくなるが, バラツキが大きく刺々し い曲線になる.このため, 平滑化パラメータ $(b)$ の選択は最終的に分散とバイアスのトレードオフ の問題に帰着する.このときによく利用される基 準が, 平均 2 乗誤差の推定量としてのクロス・バ リデーション $(C V)$ 平方和の最小化である ${ }^{3,4)}$. $C V$ 平方和は以下の式で表される.

$$
C V(b)=\frac{1}{k} \sum_{i=1}^{\mathrm{k}}\left(\frac{h\left(t_{i}\right)-\hat{h}\left(t_{i}\right)}{1-S}\right)^{2}
$$

ここで, $h\left(t_{i}\right)$ は時点 $t_{i}$ のハザード関数, $\hat{h}\left(t_{i}\right)$ は 時点 $t_{i}$ の平滑化ハザード関数, $S=\frac{K(0)}{b}$ である.

TS-1 カプセル使用成績調査の中間集計では, 1 週間単位あるいは 2 週間単位で臨床検査の測定お よび臨床所見を評価する症例が多かったことを考 慮し， $7,14,21,28$ の中で $C V$ 平方和の最小に なる值を平滑化パラメータ（b) として設定した。

\section{2 核関数}

一般的に用いられている Epanechnikov Kernel を選択した.しかし, 核関数の平滑化は区間の 端点で推定精度が悪くなる傾向があるため5), Modified Epanechnikov Kernel を核関数として
選択した ${ }^{6)}$. Modified Epanechnikov Kernel は以 下の式で表される.

1) $b \leq t \leq t_{k}-b$ のとき,

Epanechnikov Kernel :

$K(x)=0.75\left(1-x^{2}\right)$ for $-1 \leq x \leq 1$

2) $0<t<\mathrm{b}$ のとき, $q=\frac{t}{b}$ に対して

Modified Epanechnikov Kernel :

$$
\begin{aligned}
& K(x)=0.75\left(1-x^{2}\right)\left(\alpha_{E}+\beta_{E} x\right) \\
& \quad \text { for }-1 \leq x \leq \mathrm{q}
\end{aligned}
$$

3) $t_{k}-b<t<t_{k}$ のとき, $q=\frac{t_{k}-t}{b}$ に対して

Modified Epanechnikov Kernel :

$$
\begin{aligned}
& K(x)=0.75\left(1-x^{2}\right)\left(\alpha_{E}+\beta_{E} x\right) \\
& \quad \text { for }-q \leq x \leq 1
\end{aligned}
$$

ここで, $x=\frac{t-t_{i}}{b}, \quad \alpha_{E}=\frac{64\left(2-4 q+6 q^{2}-3 q^{3}\right)}{(1+q)^{4}\left(19-18 q+3 q^{2}\right)}$, $\beta_{E}=\frac{240(1-q)^{2}}{(1+q)^{4}\left(19-18 q+3 q^{2}\right)}$ である.

\section{結果}

\section{1. 平滑化パラメータ}

9 個の解析項目に対して, $C V$ 平方和が最小に なる值 $(b)$ を算出した. 2 項目 (白血球数, 口内 炎) で $b=14,6$ 項目 (好中球数, 血小板数, 食欲 不振, 悪心・嘔吐, 下痢, 全身倦急感) で $b=21$, 1 項目 (血色素量)で $b=28$ が選択された. 各解析 項目の好発時期の比較に強い関心があることを考 慮して, 平滑化パラメータを全項目ともに $b=21$ に設定して平滑化ハザード関数の推定を行った。

\section{2. 血液学的検査項目}

結果を Fig. 3 に示す. 血液学的検查項目では, 1 クール目の投薬期間 (1 日～28日), とくに薬剤 の投薬を開始してから 10 日近辺で発現率がピー クとなり，その後は休薬期間 (29日〜42 日) の最 終日に相当する投与 42 日まで漸減した。

\section{3. 臨床所見項目}

結果を Fig. 4 に示す. 臨床所見項目では, 1 クー ル目の投薬期間 (1 日〜28日)，とくに薬剤の投薬 を開始してから 7 日〜10日近辺で発現率がピー クとなり，その後は休薬期間 (29 日〜 42 日) の最 終日に相当する投与 42 日まで漸減した。食欲不 振, 悪心・嘔吐は, 他の臨床所見項目よりも少し 
薬剤疫学 Jpn J Pharmacoepidemiol, 8(1) Sept 2003:41

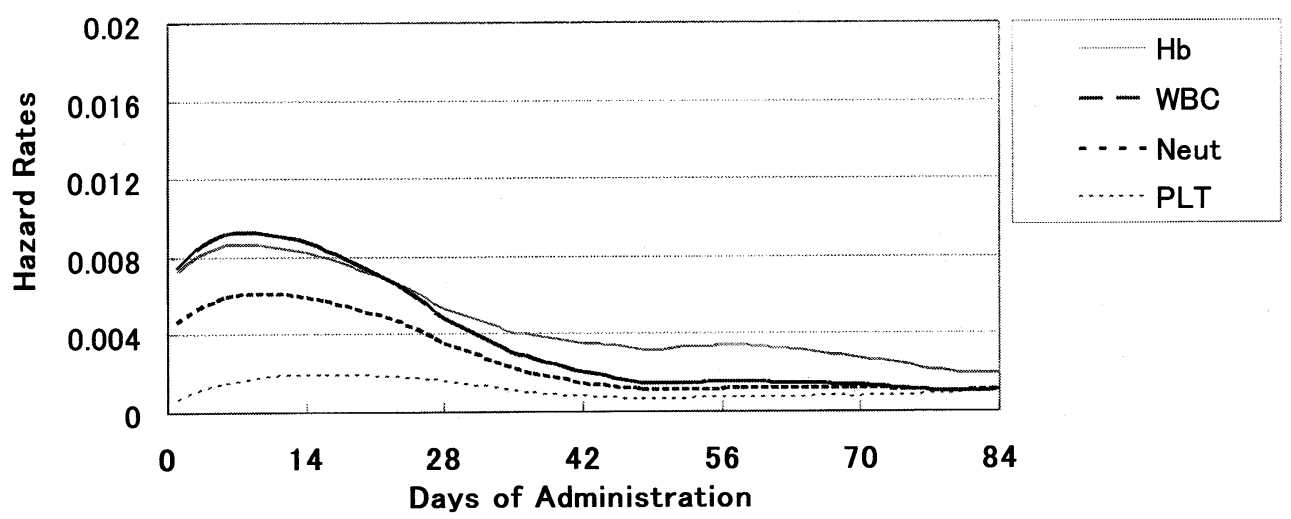

Fig. 3 Occurrences of adverse events using smoothed hazard functions (smoothing parameter $=21$ )

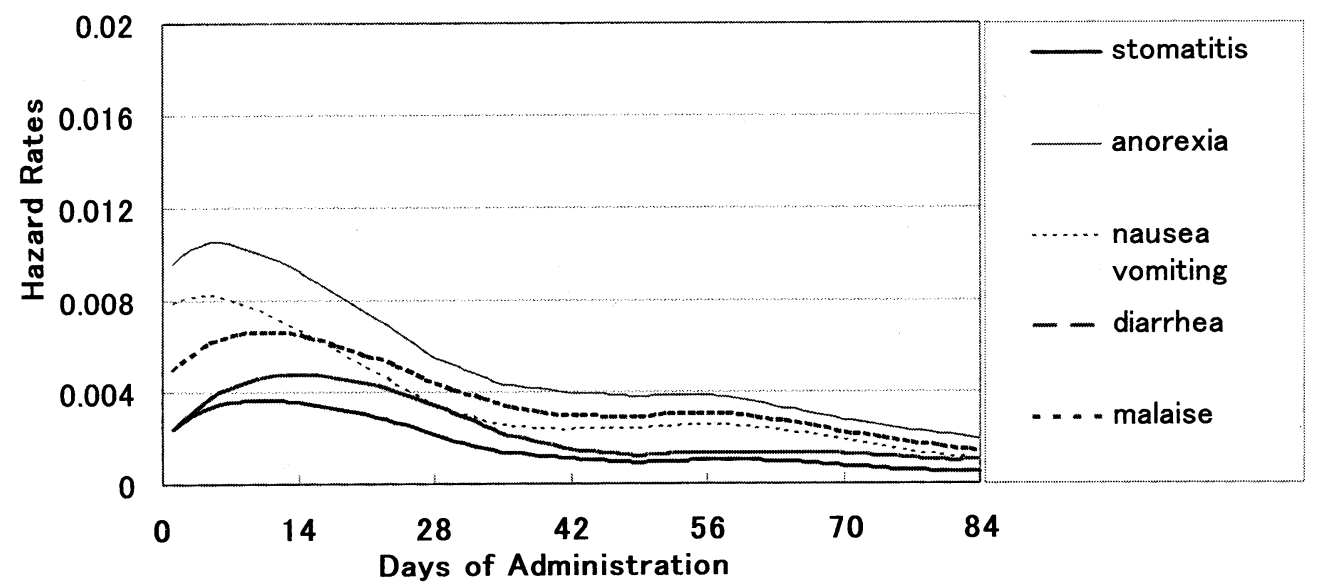

Fig. 4 Occurrences of adverse events using smoothed hazard functions (smoothing parameter $=21$ )

早い時期にピークを迎えていた. 2 クール目の投 与再開とともに発現率は再び上昇したが，これら の有害事象の発現率は 1 クール目の発現率と比較 して小さかった.

\section{考察}

\section{1. ハザード関数の有用性}

医薬品の使用実態下で実施される市販後調査で は，投与期間および観察期間が長くなるにつれて 症例数が減り, 有害事象（副作用）の発現件数が 見かけ上少なくなる。したがって，発現割合だけ で結果の解釈を行うと有害事象（副作用）の発現
を過小に評価してしまう。しかしながら，市販後 調査では発現割合を用いた安全性データの要約が 中心で, 症例毎の投与期間および観察期間の違い を考慮した解析はほとんど行われていない. 症例 毎の投与期間および観察期間の違いを考慮した解 析としては, 有害事象 (副作用) の初発時期に着 目して, Kaplan-Meier 法を用いて累積発現率曲 線を推定することが考えられる。しかしながら， 累積発現率曲線から有害事象（副作用）の発現パ ターン（好発時期）を推定することは容易ではな い.

そこで, 有害事象 (副作用) の発現パターン（好 
発時期）を推定するために，ハザード関数を適用 することを考えた. 結果として, 有害事象の発現 率のピーク時期が 7 日〜 10 日近辺であること, 食 欲不振, 悪心・嘔吐は他の検査項目に比べて少し 早い時期にピークを迎えていることがわかった。

ハザード関数を適用することで, 有害事象の好 発時期を視覚的に捉えることができた。 また，有 害事象間の発現パターンの違いについて容易に比 較検討することができた。これらの成果は, 従来 の発現割合を用いた安全性の解析では得られな かったものである.

本研究では, イベントの初発時期に着目してハ ザード関数の推定を行った。しかしながら, 初発 時期に限定する必要はなく, 同種のすべてのイべ ントすなわち再発イベントに対する解析もハザー ド関数を用いて行うことができる. TS-1 カプセ ル使用成績調査の中間集計でも, 血液学的検查項 目, 臨床所見項目において再発イベントが多く認 められている.イベントの初発時期だけでなく, 再発時期を取り扱うことでさらに精度の高い解析 結果を得ることが期待される。

以上述べたように，ハザード関数は，医薬品の 安全性の評価において, 有用な解析手法の 1 つで あると考える。

\section{2. 解析結果の安定性}

ハザード関数は投与日毎の変動が激しいうえ に, 推定量としても不安定であるため, 平滑化を 用いてハザード関数の推定を行った。一般に，平 滑化ハザード関数の形状は核関数および平滑化パ ラメータの值に影響される。しかし，核関数の種 類にはあまり影響しないことが先行研究の結果で 示されている7).そこで, 区間の端点における推定 精度を考慮して Modified Epanechnikov Kernel を核関数として選択した。平滑化パラメータの值 としては, 各解析項目の好発時期の比較に強い関 心があったため, 全項目ともに $b=21$ に設定し, 平滑化ハザード関数の推定を行った．平滑化パラ メータが異なれば, 推定される曲線の形状が大き く異なることも考えられる。しかしながら, 平滑 化パラメータを $b=7,14,28$ に設定した時の曲線 の形状と比較しても, 平滑化パラメータの違いに
よる曲線の形状の差はほとんどなく，発現率の ピークはすべて 7 日〜10 日近辺にあった.このた め, 解析結果は頑健であると考える.

\section{3 . 今後の課題（区間打ち切り）}

すでに述べたように，本研究ではイベントの初 発時期に着目して解析を行った.しかしながら, イベントの発現時期は臨床検査項目の測定時期お よび臨床所見項目の評価時期に大きく依存する. たとえば，通院間隔が 1 週間の外来患者の場合， 薬剤の投与を開始してから 1 週間後にイベントの 発現が認められても, それは薬剤の投与開始から 7 日後のいずれかの日にイベントが起きたので あって, 7 日後にイベントが起きたことだけを意 味するわけではない.この状況をイベントの発現 時期は「区間打ち切りを受けている」という。現 実の市販後調査では, 臨床検查項目の測定および 臨床所見項目の評価を毎日行うことは不可能であ るため, ほとんどの症例はイベントの発現時期に 関して区間打ち切りを受けていると考えられる. TS-1 カプセル使用成績調查の中間集計でも，添 付文書に投与期間中は 2 週間に 1 回以上，とくに 1 クール目は頻回に臨床検査を実施することが記 載されており，1 週間隔あるいは 2 週間隔で臨床 検査の測定および臨床所見の評価を行う患者が多 かった.このため，イベントの発現時期を正確に 捉えるためには，区間打ち切りを考慮した解析が 必要である. 区間打ち切りを考慮した解析方法に ついては, 今後検討を行っていく必要があると考 える。

\section{結 論}

市販後調査では，症例毎に投与期間および観察 期間が異なる。しかし，これらの違いを考慮した 解析はほとんど行なわれていない.そこで TS-1 カプセル使用成績調査の中間集計を対象として, 安全性評価におけるハザード関数の有用性につい て検討を行った。ハザード関数を用いることによ り，有害事象の好発時期を視覚的に捉えることが できた. ハザード関数は, 医薬品の安全性の評価 において有用な解析手法の 1 つであると考える. 
薬剤疫学 Jpn J Pharmacoepidemiol, 8(1) Sept 2003:43

\section{謝辞}

草稿の段階で貴重なコメントを頂きました先生方に厚く お礼を申し上げます。

\section{文献}

1）中上節夫, 森川敏彦. 医薬統計学一医薬品開発の ための統計学 サイエンティスト社, 1992 : 50523.

2）伊藤国夫. 安全性モニタリングを実施したTS 1 カ プセルの全例使用成績調查一中間集計結果と実施上 の問題点一. 薬剤疫学 $2001 ; 6$ (Suppl) : S 22-3.
3）丹後俊郎。統計モデル入門．朝倉書店，2000：1035.

4) Hastie TJ, Tibshirani RJ. Generalized Additive Models. London : Chapman and Hall, 1990 : 46-7.

5）柏木宣久, 柳本武美. 平滑化法とそのソフトウエア. 応用統計学 $1990 ； 19$ (2)：79-92.

6) Klein JP, Moeschberger ML. Survival Analysis Techniques for Censored and Truncated Data. New York : Springer-Verlag, 1997 : 152-63.

7) Hess KR, Serachitopol DM, Brown BW. Hazard function estimators: a simulation study. Statistics in Medicine $1999 ; 18$ (22) : 3075-88. 